\title{
TUGAS PEREKONOMIAN INDONESIA \\ REVIEW JURNAL
}

"Sektor Pariwisata Indonesia"

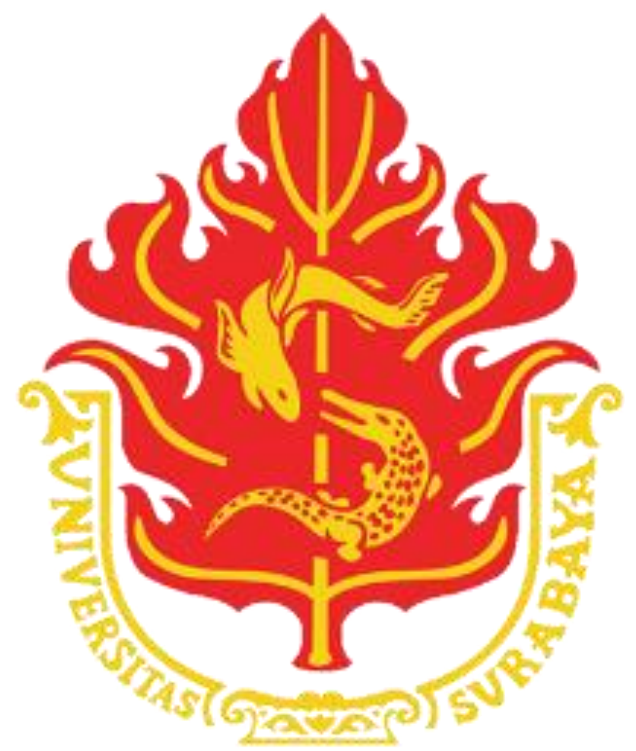

Disusun Oleh :

1. Albertus Petrus Atdjas 130217218

2. Reginna Margaretha May 130218924

3. I Komang Widia Dharma Setiawan 130317202

KP A

FAKULTAS BISNIS \& EKONOMIKA

UNIVERSITAS SURABAYA 


\begin{tabular}{|l|l|}
\hline Judul & Sektor Pariwisata Indonesia \\
\hline Jurnal & Boosting Indonesia's Tourism Sector To Be Competitive \\
\hline Volume \& Halaman & Volume 10;6 Halaman \\
\hline Tahun & Maret 2020 \\
\hline Penulis & $\begin{array}{l}\text { Ahmad Zafrullah Tayibnapis } \\
\text { Made Siti Sundari }\end{array}$ \\
\hline Reviewer & $\begin{array}{l}\text { Albertus Petrus Atdjas } \\
\text { Reginna Margaretha May } \\
\text { I Komang Widia Dharma Setiawan }\end{array}$ \\
\hline Tanggal & 07 November 2020 \\
\hline Alamat Doi & \\
\hline
\end{tabular}




\section{RANGKUMAN}

Salah satu sektor yang paling berpengaruh terhadap kontribusi pendapatan negara adalah sektor pariwisata. Hingga saat ini sektor pariwisata masih diandalkan untuk menutup defisit transaksi berjalan dan anggaran negara. Trend masyarakat saat ini telah berpindah dari kepemilikan barang menjadi konsumsi perjalanan dan pengalaman yang di alami. Sehingga saat ini, berlibur tidak lagi hanya sebatas gaya hidup melainkan sebuah kebutuhan. Perkembangan teknologi yang semakin modern juga membuat banyak kemajuan di sektor pariwisata. Trend belanja online meningkatkan penjualan tiket penerbangan online, tiket travel, tour guide dan pemesanan hotel online semakin meningkat. Selain itu, banyak wisatawan memposting pengalaman liburan mereka di akun instagram, twitter, vlog youtube, dan di web blog semakin memperluas promosi pariwisata. Sedangkan permasalahan yang cukup sering dialami adalah meningkatkan target kunjungan wisatawan ke Indonesia yang masih tergolong cukup sulit. Tujuan penelitian ini adalah untuk menganalisis permasalahan yang dialami sektor pariwisata Indonesia dan juga upaya yang telah dilakukan dan harus dilakukan dalam meningkatkan perkembangan sektor pariwisata Indonesia.

Berdasarkan penelitian yang telah dilakukan, ditemukan beberapa masalah. Masalah pertama adalah keterbatasan anggaran untuk promosi dan harga persaingan dan paket - paket menarik yang tidak tersampaikan dengan baik kepada turis mancanegara. Salah satu contoh adalah promosi program "pesona Indonesia" yang tidak memberikan hasil maksimal karena tidak ada promosi intensif luar negri sehingga kurang menarik minat turis mancanegara. Berdasarkan data statistis, jumlah kunjungan wisatawan mancanegara pada 1 september 2019 hanya mencapai 9,31 juta kunjungan, sedangkan target 2019 adalah 18 juta kunjungan wisatawan mancanegara. Hal ini sangat disayangkan, padahal daya saing pariwisata Indonesia meningkat ke peringkat 40 dari total 140 negara dengan perolehan skor sebesar 4,3. Keunggulan Indonesia adalah segi harga yang murah namun kelemahannya adalah pelestarian lingkungan yang sangat minim.

Selain itu keterbatasan jumlah pelabuhan wisata, armada wisata (kapal, pesawat, mobil), dan akses menuju kawasan wisata yang cukup sulit dan berbahaya untuk dilalui juga menjadi masalah serius. Salah satu conto adalah wisata kawah ijen, untuk mencapai api biru harus melalui jalanan yang curam dan terjal, tak sedikit turis tergelincir dan saling bersenggolan disana. Selain itu terbatasnya infrastruktur pariwisata, terbatasnya peralatan keamanan, minimnya ketersediaan teknologi informasi, pelayanan pariwisata yang masih 
sangat rendah serta banyaknya masalah terkait kebersihan di setiap destinasi wisata yang menghambat perkembangan pariwisata Indonesia.

Untuk meningkatkan sektor pariwisata Indonesia, ada 6 program yang telah diluncurkan yakni; mengembangkan destinasi wisata unggul, meningkatkan daya saing, meningkatkan keanekaragaman pariwisata, meningkatkan integrasi pariwisata, memperkuat sebagai tujuan utama destinasi wisata Asia, serta memperkuat sebagai tujuan destinasi wisata dunia. Pada tahun 2020 target kunjungan wisatawan mancanegara adalah 21.600.000 kunjungan dengan 5 tujuan destinasi utama, Danau Toba di Provinsi Sumatera Utara, Candi Borobudur di Provinsi Jawa Tengah, Labuan Bajo di Provinsi Nusa Tenggara Timur, Mandalika di Provinsi Nusa Tenggara Barat, dan Likupang di Provinsi Sulawesi Utara. Total anggaran yang dihabiskan untuk merealisasikan pembangunan infrastruktur di 5 destinasi utama sebesar Rp. 9,34 triliun.

Maka dari itu, untuk meningkatkan perkembangan sektor pariwisata Indonesia tidak cukup hanya dengan melakukan pembangunan infrastruktur fisik, seperti perbaikan jalan, pembangunan hotel, pembangunan pelabuhan dan lainya namun juga butuh kontrol langsung dari pemerintah, kebijakan terhadap sektor pariwisata dan pengelolaan sumber daya manusia yang maksimal serta strategi pemasaran ke negara luar. 